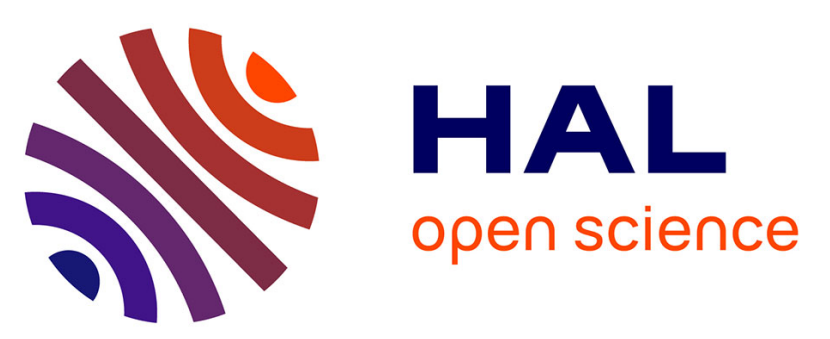

\title{
A mouse model of disseminated mantle cell lymphoma highlights a lack of activity of estrogen receptor $\beta$ agonists toward tumor burden
}

Simon Body, Anna Esteve-Arenys, Clara Recasens-Zorzo, Xavier Troussard, Gaël Roué, Brigitte Sola

\section{To cite this version:}

Simon Body, Anna Esteve-Arenys, Clara Recasens-Zorzo, Xavier Troussard, Gaël Roué, et al.. A mouse model of disseminated mantle cell lymphoma highlights a lack of activity of estrogen receptor $\beta$ agonists toward tumor burden. Leukemia \& lymphoma, In press, 59 (7), pp.1726-1729. 10.1080/10428194.2017.1399313 . hal-01669330

\section{HAL Id: hal-01669330}

https://hal-normandie-univ.archives-ouvertes.fr/hal-01669330

Submitted on 21 Dec 2017

HAL is a multi-disciplinary open access archive for the deposit and dissemination of scientific research documents, whether they are published or not. The documents may come from teaching and research institutions in France or abroad, or from public or private research centers.
L'archive ouverte pluridisciplinaire HAL, est destinée au dépôt et à la diffusion de documents scientifiques de niveau recherche, publiés ou non, émanant des établissements d'enseignement et de recherche français ou étrangers, des laboratoires publics ou privés. 


\section{A mouse model of disseminated mantle cell lymphoma highlights a lack of activity of estrogen receptor $\beta$ agonists toward tumor burden}

\begin{tabular}{|r|l|}
\hline Journal: & Leukemia and Lymphoma \\
\hline Manuscript ID & GLAL-2017-0783.R1 \\
\hline Manuscript Type: & Letter to the Editor \\
\hline Date Submitted by the Author: & n/a \\
\hline Complete List of Authors: & $\begin{array}{l}\text { Body, Simon; INSERM U1245, UNICAEN } \\
\text { Esteve-Arenys, Anna; Institut d'Investigacions Biomediques August Pi i } \\
\text { Sunycr, Division of Hcmatology and Oncolgy } \\
\text { Recassens-Zorzo, Clara; Institut d'Investigacions Biomediques August Pi i } \\
\text { Sunyer, Division of Hematology and Oncolgy } \\
\text { Troussard, Xavier; INSERM U1245, UNICAEN; Laboratoire d'Hématologie } \\
\text { Biologique } \\
\text { Roué, Gaël; Institut d'Investigacions Biomediques August Pi i Sunyer, } \\
\text { Division of Hematology and Oncolgy; Hospital Vall d'Hebron, Department of } \\
\text { Hematology } \\
\text { Sola, Brigitte; INSERM U1245, UNICAEN }\end{array}$ \\
\hline Keywords: & $\begin{array}{l}\text { Lymphocytes < Hematopoiesis, Cell Lines and Animal Models < Neoplasia, } \\
\text { Immunotherapeutic approaches < Neoplasia, Lymphoma and Hodgkin } \\
\text { disease < Neoplasia }\end{array}$ \\
\hline \multicolumn{2}{|c}{} \\
\hline
\end{tabular}

\section{SCHOLARONE ${ }^{n}$}

Manuscripts 


\title{
LETTER TO THE EDITOR
}

\section{A mouse model of disseminated mantle cell lymphoma highlights a lack of activity of estrogen receptor $\beta$ agonists toward tumor burden}

\author{
Simon Body, ${ }^{1}$ Anna Esteve-Arenys, ${ }^{2}$ Clara Recasens-Zorzo, ${ }^{2}$ Xavier Troussard, ${ }^{1,3}$ Gaël Roué ${ }^{2,4}$ \\ \& Brigitte Sola ${ }^{1, *}$ \\ ${ }^{1}$ Normandie Univ, INSERM UMR1245, UNICAEN, Caen, France \\ ${ }^{2}$ Division of Hematology and Oncology, IDIBAPS, Barcelona, Spain \\ ${ }^{3}$ Laboratoire d'Hématologie Biologique, CHU Côte de Nacre, Caen, France \\ ${ }^{4}$ Molecular Genetics Unit, Department of Hematology, University Hospital Vall d'Hebron, \\ Barcelona, Spain
}

* Corresponding author : Brigitte Sola. Address : MICAH team, UFR Santé, CHU Côte de Nacre, 14032 Caen Cedex, France. Mail : brigitte.sola@unicaen.fr

Running head : Lack of ERß agonist activity on $\mathrm{MCL}$ 
Mantle B lymphoma (MCL) is a rare, still incurable, aggressive malignant hemopathy of mature B cells [1]. In the bone marrow and secondary lymphoid organs, tumor cells are connected with their environment (stromal cells, endothelial cells, osteoblasts, osteoclasts, immune cells, etc.) by cytokines, adhesion proteins and their respective receptors [2]. These interactions are responsible for a mechanism known as CAM-DR (cell adhesion-mediated drug resistance) [2]. This is why current therapies attempt to target both tumor cells and the tumor microenvironment (TME).

Estrogens regulate numerous physiological processes through their binding to estrogen receptors (ER) of $\alpha$ and $\beta$-types. However, while activated ER $\alpha$ enhances cell proliferation, activated ERß inhibits cell proliferation and induces apoptosis. Normal and malignant immune cells express both types of ER but predominantly ER $[4]$. This property has been successfully used to selectively inhibit growth and induce apoptosis in an in vivo model of lymphoma [5]. In this study, the Granta519 mantle cell lymphoma (MCL) cell line was engrafted s.c. into nude mice. Treatment of mice with diarylpropionitrile (DPN) led to the inhibition of tumor cell growth. The biological effects of DPN were mediated by the inhibition of BAFF (B-cell activating factor) and GBR7 (growth factor receptor-bound protein 7) survival factors, and VEGF (vascular endothelial growth factor or VEGF), an angiogenic factor.

According to the dependency of MCL cells with their TME, we suspected that MCL tumor cells-stroma interactions would not be the same for MCL cells engrafted s.c. or in their physiological niche. We engineered four cell lines: JeKo1-mCherry-Luc, Z138-Luc, REC1-GFPLuc and Granta519-GFP from their respective parental cell lines. Cells were then injected i.v. into NOD-SCID IL2Rynull (NSG) mice $(n=6)$. All animals recapitulated bona fide $M C L$ disease. Tumor cells having luciferase activity were detected by bioluminescence imaging (BLI) with a 
kinetics dependent of each cell line: JeKo1 being the most aggressive and REC1 the less aggressive cells (Fig S1). BLI examination indicated that tumor cells housed in hematopoietic organs (bone marrow, spleen) and, in some cases, in non-hematopoietic organs (liver, lung, kidney). The identity of tumor cells was verified at the time of mice euthanasia by cytometry analysis of CD20+ cells purified from infiltrated organs (Table 1 ).

We analyzed the expression of ER $\alpha$ and ERß on a panel of MCL cells both at the MRNA and protein levels. ER $\alpha$ mRNAs were absent or very low in all cell lines (data not shown) according to previous data [5]. In contrast, ER $\beta$ was expressed in all MCL cell lines (including GFP/mCherry/Luc expressing JeKo1, Granta519, REC1 and Z138 cells) tested although at various levels (Fig 1A). We next assessed in vivo the effects of both DPN and ERB-041 (or 2(3-Fluoro-4-hydroxyphenyl)-7)vinyl-1,3-benzoxazol-5-ol), another selective ER $\beta$ agonist [6], on MCL dissemination and growth. Z138-Luc or REC1-GFP-Luc cells were injected in NSG mice. The same day, mice were separated into three groups $(n=3)$ receiving: vehicle $(0.01 \%$ DMSO), DPN or ERB-041 both at the concentration of $1 \mathrm{mg} / \mathrm{kg}$. Drugs and vehicle were injected i.p. 5 days a week. BLI was recorded each week starting at day 7. Mice were euthanized at day 31 (Z138-Luc) or day 41 (REC1-GFP-Luc). As shown Fig 1B, DPN or ERB-041 treatments did not modify the engraftment properties of MCL tumor cells, since all mice were engrafted with luciferase-positive cells, or their homing, since infiltrated organs were the same among the different groups. Moreover, the number of CD45+ tumor cells in each organ was also similar between the three groups (Fig S2). In sharp contrast with published data [5], ERß agonists have no effects on tumor cells growth in this in vivo model. In vitro, although DPN was more active than ERB-041 and, Granta519 being the cell line with the highest sensitivity, we did not observed any dose-dependent effect of ER $\beta$ agonists on cell proliferation (Fig S3). 
One main action of DPN is to counteract migration and invasion [5]. We next tested the effect of ERB-041 and DPN on MCL cells in two in vitro assays : one dedicated to chemotaxis, the other one to invasion. Our data indicated clearly that ERB-041 and DPN had no inhibitory effects on migration (Fig 1C and Fig S4A) or invasion (Fig S4B).

Finally, since DPN was reported to inhibit VEGF synthesis [5], we looked at the effects of DPN and ERB-041 on angiogenesis using the tube formation assay. As shown Fig 1D and Fig S5, the density of tubes was similar in the ER $\beta$ - and vehicle-targeted groups. ER $\beta$ agonists had no effect on the formation of structures resembling a microvasculature bed. We then measured VEGF synthesis in conditioned medium of cultured $\mathrm{MCL}$ cells treated with ER $\beta$ agonists or vehicle using ELISA (Fig S2C, Fig 1E). Our data confirmed that the quantity of VEGF secreted MCL tumor cells remained the same after DPN or ERB-041 treatments.

Subcutaneous injections are commonly used for the engraftment of human MCL cells in immunocompromised mice. However, this model is imperfect and does not recapitulate the interactions between the TME and tumor cells. In this study, we present a convenient and reproducible in vivo model that reproduces human $\mathrm{MCL}$ pathology. After i.v. injection of engineered luciferase-expressing MCL cell lines, we observed that tumor cells preferentially colonize hematopoietic organs such as bone marrow and spleen, and other common metastatic sites such as brain and gut. The lack of in vivo effect of ERß agonists in this preclinical model could be due to a protective CAM-DR. Indeed, in this in vivo model, MCL cells are in close contact with stromal cells delivering anti-apoptotic and pro-proliferative signals likely bypassing the effect of the drugs [7]. Alternatively, the pharmacokinetics distribution of ER $\beta$ agonists may be different in the model described here and the one of Yakimchuk and colleagues [5]. A low concentration of ER $\beta$ agonists could be present in the physiologic niches such as the bone marrow explaining the lack of efficiency for the treatment. Finally, 
the anti-angiogenic properties of ERß agonists highlighted in the work of Yakimchuk and colleagues [5], may have a greater impact on the proliferation of tumor cells in the s.c. model, where the neovascularization is crucial to bring to the tumor nutriments and oxygen. By contrast, hematopoietic organs are less dependent on neovascularization.

However, our in vitro experiments confirmed that, although ER $\beta$ are well-expressed in the MCL cell lines, ER $\beta$ agonists had no effect on proliferation, migration, invasion or VEGF production, emphasizing the in vivo results. Interestingly, we found previously that, although able to decrease multiple myeloma cell proliferation, ERß agonists are inefficient in vivo [8]. In conclusion, our results highlight a lack of effects of ERß agonists as single agents in mice. Nonetheless, as it has been described that estrogen play an important role in BCR pathway regulation [9], consequently further investigations would be required to assess the efficacy of ER $\beta$ agonists in association with B-cell receptor inhibitors, like ibrutinib.

\section{Acknowledgements}

The work has been financially supported by grants from ITMO Biologie cellulaire, développement et évolution (to BS), Ligue contre le Cancer-Comité de l'Orne, and Fondo de Investigación Sanitaria PI12/01847 and PI15/00102, European Regional Development Fund (ERDF) "Una manera de hacer Europa" (to GR). SiBo obtained a mobility grant from Cancéropôle Nord-Ouest. AE-A and CR-Z were recipients of predoctoral fellowships from Ministerio de Ciencia e Innovación and Instituto de Salud Carlos III (grant PIE13/00033), respectively.

\section{Conflict of interest}


The authors declare no conflicts of interest.

\section{Authors contribution}

$\mathrm{SB}, \mathrm{AE}-\mathrm{A}$, and $\mathrm{CR}-\mathrm{Z}$ performed the research and analyzed the data. $\mathrm{XT}$ provided essential support. GR and BS designed and supervised the study. SB and BS wrote the paper. All authors read the final version of the manuscript and agree with its content and submission.

\section{References}

1. Campo E \& Rule S. Mantle cell lymphoma: evolving management strategies. Blood 2014; 125: 48-55.

2. Inamdar AA, Goy A, Ayoub NM, et al. Mantle cell lymphoma in the era of precision medicine-diagnosis, biomarkers and therapeutic agents. Oncotarget 2016; 7: 4869248731.

3. Shain $\mathrm{KH}$, Dalton WS, Tao J. The tumor microenvironment shapes hallmarks of mature Bcell malignancies. Oncogene 2015; 34: 4673-4682.

4. Yakimchuk K, Jondal M, Okret S. Estrogen receptor alpha and beta in the normal immune system and in lymphoid malignancies. Mol Cell Endocrinol 2013; 375: 121-129.

5. Yakimchuk K, Hasni MS, Guan J, et al. Inhibition of lymphoma vascularization and dissemination by estrogen receptor b agonists. Blood 2014; 123: 2054-2061.

6. Chaudhary SC, Singh T, Talwelkar SS, et al. Erb-041, an estrogen receptor beta agonist inhibits skin photocarcinogenesis in SKH-1 hairless mice by down-regulating WNT signaling pathway. Cancer Prevent Res 2014; 7: 186-198.

7. Burger JA, Ford RJ. The microenvironment in mantle cell lymphoma: Cellular and molecular pathways and emerging targeted therapies. Semin Cancer Biol 2011; 21: 308312.

8. Fidalgo M, Ben Younes K, Body S, Ben Aissa-Fennira, Haelewyn B, Sola B. Agonists of estrogen receptor $\beta$ have limited anti-myelome activity. Blood e-Letters, September 15 , 2015. http://www.bloodjournal.org/content/123/13/2054

9. Ladikou EE, Kassi E. The emerging role of estrogen in B cell malignancies. Leuk Lymphoma. 2017; 58:528-539.

10. Moros A, Bustany S, Cahu J, et al. Antitumoral activity of lenalidomide in in vitro and in vivo models of mantle cell lymphoma involves the destabilization of cyclin D1/p2 $7^{\mathrm{KIP} 1}$ complexes. Clin Cancer Res 2014;20:393-403.. 


\section{Figure 1. ER $\beta$ are present on $M C L$ cells but ER $\beta$ agonists do not affect} migration, invasion, nor angiogenesis

A. Proteins were purified from cultured MCL cell lines including GFP/mCherry/Luc-expressing cells with the M-PER ${ }^{\mathrm{TM}}$ Mammalian Protein Extraction Reagent (Thermo Fisher Scientific), quantified, separated by SDS-PAGE, blotted onto nitrocellulose mambrane and incubated with antibodies against ERß (sc-8974, Santa Cruz Biotech.) or $\beta$-actin (sc-47778) as a control for gel loading and transfer. Our procedure has been described previously [10]. A band at 55 $\mathrm{kDa}$, specific for $\mathrm{ER} \beta$,is arrowed; * refers to an unspecific band at $75 \mathrm{kDa}$. B. In vivo experiments were conducted in accordance with the recommendations of EEC (86/609/CEE) and with the approval of the Animal Experimental Ethics Committee of our institution (UBCEEA agreement 251/15). Z138-GFP-Luc, REC1-GFP-Luc, JeKo1-mCherry-Luc, and Granta519-GFP cell lines were engineered using lentivirus or retrovirus infections. Male NSG mice, $n=3$ per group (age 6-8 weeks), were injected i.v. with $10^{7}$ cells in a final volume of $100 \mu \mathrm{l}$. The same day, mice were separated into three groups receiving: vehicle $(0.01 \%$ DMSO), DPN or ERB-041 both at the concentration of $1 \mathrm{mg} / \mathrm{kg}$. Drugs and vehicle were injected i.p. 5 days a week. Tumor engraftment was determined weekly by bioluminescence imaging (BLI). For this aim, mice were injected i.p. with $75 \mathrm{mg} / \mathrm{kg}$ of D-luciferine and then analyzed on an Aequoria Luxiflux bioluminescent device equipped with an ORCA-ER camera (Hamamatsu). Mice were euthanized at day 31 (Z138-Luc) or day 41 (REC1-GFP-Luc). Endpoint BLI signal is shown for each treatment group. C. MCL cells were treated in vitro with DPN or ERB-041 (100 nM or $1 \mu \mathrm{M}$ for $48 \mathrm{~h}$ or $72 \mathrm{~h}$ ) or vehicle and assayed for migration. 
Cells ( $5 \times 10^{5}$ cells per insert) were suspended in RPMI 1640 medium containing $0.5 \%$ bovine serum albumin (BSA). They were seeded in the top chamber of transwell inserts (Millicell ${ }^{\circledR}$ Hanging Cell Culture Inserts $5 \mu \mathrm{m}$ PET, Millipore). Filters were transferred to wells containing RPMI 1640 medium with recombinant human stromal cell-derived factor 1 (SDF1, $200 \mathrm{ng} / \mathrm{ml}$, R\&D Systems) as chemoattractant. Plates were then incubated for $4 \mathrm{~h}$ at $37^{\circ} \mathrm{C}$, and the number of cells migrated in the lower chambers was counted by flow cytometry. As an example, the results obtained for the $Z 138$ cell line treated with 0.1 or $1 \mu \mathrm{M}$ ERB-041 or DPN for $48 \mathrm{~h}$ are shown. The percentage of migrating cells (treated vs. vehicle) for each culture condition is plotted on the graph. D. HUVECs were plated onto a layer of Matrigel (BD Bioscience) at a density of $4 \times 10^{4}$ cells/well. Cells were treated with supernatants of ERB041-treated (100 nM or $1 \mu \mathrm{M}$ for $4 \mathrm{~h}$ ) or vehicle-treated cells as a control. After $24 \mathrm{~h}$, tubular structures were photographed under a microscope (Olympus IX2-SL). The number of formed capillary tubes was counted in 11 independent fields (Fig S5A) of each well from each culture. The experiment has been done twice with triplicate samples. The number of tubes are plotted in the histograms. E. The concentration of VEGF was measured with an ELISA assay (Quantikine ELISA Human VEGF, R\&D systems) using the supernatants of Granta519 and JeKo-1 cells treated by ERB-041 (1 $\mu \mathrm{M}$ for $48 \mathrm{~h}$ ) according to the manufacturer's recommendations. Samples were assayed in triplicate. The concentration of synthetized VEGF in each culture condition was deduced from the standard curve shown in Fig S5B . ns, non significant; ${ }^{*}, p<0.05 ;^{* *}, p<0.01 ;^{* * *}, p<0.001$ with the Student's $t$-test. 
Table 1. Flow cytometry analysis of infiltrated organs in engrafted NSG mice

\begin{tabular}{|l|l|l|l|l|l|l|l|l|}
\hline Cell line & Mouse & Spleen & Blood & $\begin{array}{l}\text { Bone } \\
\text { marrow }\end{array}$ & Liver & Lung & Kidney & Testis \\
\hline JeKo1-mCherry-Luc* & J1 & 5 & no & 44 & no & nd & nd & no \\
\hline & J2 & 15 & no & 59 & no & nd & nd & no \\
& J3 & 7 & 7 & 45 & no & nd & nd & no \\
\hline Z138-Luc** & Z3 & 22 & no & 68 & no & nd & nd & nd \\
\hline & Z4 & 24 & no & 75 & no & nd & nd & nd \\
\hline & Z5 & 38 & no & 82 & no & nd & nd & nd \\
\hline REC1-GFP-Luc*** & R4 & no & no & 4 & nd & nd & nd & nd \\
\hline & R5 & no & no & 3 & no & nd & nd & nd \\
\hline & R6 & no & no & 3 & nd & nd & nd & nd \\
\hline Granta519-GFPt & G1 & 23 & 1 & 57 & 45 & 7 & 9 & no \\
\hline & G4 & 37 & 2 & 21 & 47 & 3 & 10 & $<1$ \\
\hline
\end{tabular}

*, in the JeKo1-mCherry-Luc series, three mice were sacrificed at day 23. ${ }^{* *}$, in the Z138-Luc series, three mice were sacrificed at day $30 .{ }^{* * *}$, in the REC1-GFP-Luc series, three mice were sacrificed at day 33. + , in the Granta-GFP series, three mice died unexpectedly at day 17 , two mice were sacrificed at the same day. At the time of euthanasia, indicated organs were collected; single-cell suspensions were prepared, then stained with IOTest ${ }^{\circledR}$ CD20-PE (phycoerythrin, IM1451, FL2) or the corresponding isotype control and analyzed on an Attune acoustic focusing cytometer (Thermo Fisher Scientific). The percentage of positive cells in each organ is indicated in the table. no, no signal; nd, not done. 


\title{
LETTER TO THE EDITOR
}

\section{A mouse model of disseminated mantle cell lymphoma highlights a lack of activity of estrogen receptor $\beta$ agonists toward tumor burden}

\author{
Simon Body, ${ }^{1}$ Anna Esteve-Arenys, ${ }^{2}$ Clara Recasens-Zorzo, ${ }^{2}$ Xavier Troussard, ${ }^{1,3}$ Gaël Roué ${ }^{2,4}$ \\ \& Brigitte Sola ${ }^{1, *}$ \\ ${ }^{1}$ Normandie Univ, INSERM UMR1245, UNICAEN, Caen, France \\ ${ }^{2}$ Division of Hematology and Oncology, IDIBAPS, Barcelona, Spain \\ ${ }^{3}$ Laboratoire d'Hématologie Biologique, CHU Côte de Nacre, Caen, France \\ ${ }^{4}$ Molecular Genetics Unit, Department of Hematology, University Hospital Vall d'Hebron, \\ Barcelona, Spain \\ * Corresponding author : Brigitte Sola. Address : MICAH team, UFR Santé, CHU Côte de \\ Nacre, 14032 Caen Cedex, France. Mail : brigitte.sola@unicaen.fr
}

Running head : Lack of ERß agonist activity on $\mathrm{MCL}$ 
Mantle B lymphoma ( $M C L$ ) is a rare, still incurable, aggressive malignant hemopathy of mature B cells [1]. In the bone marrow and secondary lymphoid organs, tumor cells are connected with their environment (stromal cells, endothelial cells, osteoblasts, osteoclasts, immune cells, etc.) by cytokines, adhesion proteins and their respective receptors [2]. These interactions are responsible for a mechanism known as CAM-DR (cell adhesion-mediated drug resistance) [2]. This is why current therapies attempt to target both tumor cells and the tumor microenvironment (TME).

Estrogens regulate numerous physiological processes through their binding to estrogen receptors (ER) of $\alpha$ and $\beta$-types. However, while activated ER $\alpha$ enhances cell proliferation, activated ERß inhibits cell proliferation and induces apoptosis. Normal and malignant immune cells express both types of ER but predominantly ER 3 [4]. This property has been successfully used to selectively inhibit growth and induce apoptosis in an in vivo model of lymphoma [5]. In this study, the Granta519 mantle cell lymphoma (MCL) cell line was engrafted s.c. into nude mice. Treatment of mice with diarylpropionitrile (DPN) led to the inhibition of tumor cell growth. The biological effects of DPN were mediated by the inhibition of BAFF (B-cell activating factor) and GBR7 (growth factor receptor-bound protein 7) survival factors, and VEGF (vascular endothelial growth factor or VEGF), an angiogenic factor.

According to the dependency of MCL cells with their TME, we suspected that MCL tumor cells-stroma interactions would not be the same for MCL cells engrafted s.c. or in their physiological niche. We engineered four cell lines: JeKo1-mCherry-Luc, Z138-Luc, REC1-GFPLuc and Granta519-GFP from their respective parental cell lines. Cells were then injected i.v. into NOD-SCID IL2Rynull (NSG) mice $(n=6)$. All animals recapitulated bona fide MCL disease. Tumor cells having luciferase activity were detected by bioluminescence imaging (BLI) with a 
kinetics dependent of each cell line: JeKo1 being the most aggressive and REC1 the less aggressive cells (Fig S1). BLI examination indicated that tumor cells housed in hematopoietic organs (bone marrow, spleen) and, in some cases, in non-hematopoietic organs (liver, lung, kidney). The identity of tumor cells was verified at the time of mice euthanasia by cytometry analysis of CD20+ cells purified from infiltrated organs (Table 1).

We analyzed the expression of ER $\alpha$ and ER $\beta$ on a panel of MCL cells both at the MRNA and protein levels. ER $\alpha$ mRNAs were absent or very low in all cell lines (data not shown) according to previous data [5]. In contrast, ERß was expressed in all MCL cell lines (including GFP/mCherry/Luc expressing JeKo1, Granta519, REC1 and Z138 cells) tested although at various levels (Fig 1A). We next assessed in vivo the effects of both DPN and ERB-041 (or 2(3-Fluoro-4-hydroxyphenyl)-7)vinyl-1,3-benzoxazol-5-ol), another selective ER $\beta$ agonist [6], on MCL dissemination and growth. Z138-Luc or REC1-GFP-Luc cells were injected in NSG mice. The same day, mice were separated into three groups $(n=3)$ receiving: vehicle $(0.01 \%$ DMSO), DPN or ERB-041 both at the concentration of $1 \mathrm{mg} / \mathrm{kg}$. Drugs and vehicle were injected i.p. 5 days a week. BLI was recorded each week starting at day 7. Mice were euthanized at day 31 (Z138-Luc) or day 41 (REC1-GFP-Luc). As shown Fig 1B, DPN or ERB-041 treatments did not modify the engraftment properties of $\mathrm{MCL}$ tumor cells, since all mice were engrafted with luciferase-positive cells, or their homing, since infiltrated organs were the same among the different groups. Moreover, the number of CD45+ tumor cells in each organ was also similar between the three groups (Fig S2). In sharp contrast with published data [5], ERß agonists have no effects on tumor cells growth in this in vivo model. In vitro, although DPN was more active than ERB-041 and, Granta519 being the cell line with the highest sensitivity, we did not observed any dose-dependent effect of ER $\beta$ agonists on cell proliferation (Fig S3). 
One main action of DPN is to counteract migration and invasion [5]. We next tested the effect of ERB-041 and DPN on MCL cells in two in vitro assays : one dedicated to chemotaxis, the other one to invasion. Our data indicated clearly that ERB-041 and DPN had no inhibitory effects on migration (Fig 1C and Fig S4A) or invasion (Fig S4B).

Finally, since DPN was reported to inhibit VEGF synthesis [5], we looked at the effects of DPN and ERB-041 on angiogenesis using the tube formation assay. As shown Fig 1D and Fig S5, the density of tubes was similar in the ER $\beta$ - and vehicle-targeted groups. ER $\beta$ agonists had no effect on the formation of structures resembling a microvasculature bed. We then measured VEGF synthesis in conditioned medium of cultured MCL cells treated with ER $\beta$ agonists or vehicle using ELISA (Fig S2C, Fig 1E). Our data confirmed that the quantity of VEGF secreted MCL tumor cells remained the same after DPN or ERB-041 treatments.

Subcutaneous injections are commonly used for the engraftment of human MCL cells in immunocompromised mice. However, this model is imperfect and does not recapitulate the interactions between the TME and tumor cells. In this study, we present a convenient and reproducible in vivo model that reproduces human $\mathrm{MCL}$ pathology. After i.v. injection of engineered luciferase-expressing MCL cell lines, we observed that tumor cells preferentially colonize hematopoietic organs such as bone marrow and spleen, and other common metastatic sites such as brain and gut. The lack of in vivo effect of ERß agonists in this preclinical model could be due to a protective CAM-DR. Indeed, in this in vivo model, MCL cells are in close contact with stromal cells delivering anti-apoptotic and pro-proliferative signals likely bypassing the effect of the drugs [7]. Alternatively, the pharmacokinetics distribution of ER $\beta$ agonists may be different in the model described here and the one of Yakimchuk and colleagues [5]. A low concentration of ER $\beta$ agonists could be present in the physiologic niches such as the bone marrow explaining the lack of efficiency for the treatment. Finally, 
the anti-angiogenic properties of ERß agonists highlighted in the work of Yakimchuk and colleagues [5], may have a greater impact on the proliferation of tumor cells in the s.c. model, where the neovascularization is crucial to bring to the tumor nutriments and oxygen. By contrast, hematopoietic organs are less dependent on neovascularization.

However, our in vitro experiments confirmed that, although ER $\beta$ are well-expressed in the MCL cell lines, ER $\beta$ agonists had no effect on proliferation, migration, invasion or VEGF production, emphasizing the in vivo results. Interestingly, we found previously that, although able to decrease multiple myeloma cell proliferation, ER $\beta$ agonists are inefficient in vivo [8]. In conclusion, our results highlight a lack of effects of ERß agonists as single agents in mice. Nonetheless, as it has been described that estrogen play an important role in BCR pathway regulation [9], consequently further investigations would be required to assess the efficacy of ER $\beta$ agonists in association with B-cell receptor inhibitors, like ibrutinib.

\section{Acknowledgements}

The work has been financially supported by grants from ITMO Biologie cellulaire, développement et évolution (to BS), Ligue contre le Cancer-Comité de l'Orne, and Fondo de Investigación Sanitaria PI12/01847 and PI15/00102, European Regional Development Fund (ERDF) "Una manera de hacer Europa" (to GR). SiBo obtained a mobility grant from Cancéropôle Nord-Ouest. AE-A and CR-Z were recipients of predoctoral fellowships from Ministerio de Ciencia e Innovación and Instituto de Salud Carlos III (grant PIE13/00033), respectively.

\section{Conflict of interest}


The authors declare no conflicts of interest.

\section{Authors contribution}

$\mathrm{SB}, \mathrm{AE}-\mathrm{A}$, and $\mathrm{CR}-\mathrm{Z}$ performed the research and analyzed the data. $\mathrm{XT}$ provided essential support. GR and BS designed and supervised the study. SB and BS wrote the paper. All authors read the final version of the manuscript and agree with its content and submission.

\section{References}

1. Campo E \& Rule S. Mantle cell lymphoma: evolving management strategies. Blood 2014; 125: 48-55.

2. Inamdar AA, Goy A, Ayoub NM, et al. Mantle cell lymphoma in the era of precision medicine-diagnosis, biomarkers and therapeutic agents. Oncotarget 2016; 7: 4869248731.

3. Shain $\mathrm{KH}$, Dalton WS, Tao J. The tumor microenvironment shapes hallmarks of mature Bcell malignancies. Oncogene 2015; 34: 4673-4682.

4. Yakimchuk K, Jondal M, Okret S. Estrogen receptor alpha and beta in the normal immune system and in lymphoid malignancies. Mol Cell Endocrinol 2013; 375: 121-129.

5. Yakimchuk K, Hasni MS, Guan J, et al. Inhibition of lymphoma vascularization and dissemination by estrogen receptor b agonists. Blood 2014; 123: 2054-2061.

6. Chaudhary SC, Singh T, Talwelkar SS, et al. Erb-041, an estrogen receptor beta agonist inhibits skin photocarcinogenesis in SKH-1 hairless mice by down-regulating WNT signaling pathway. Cancer Prevent Res 2014; 7: 186-198.

7. Burger JA, Ford RJ. The microenvironment in mantle cell lymphoma: Cellular and molecular pathways and emerging targeted therapies. Semin Cancer Biol 2011; 21: 308312.

8. Fidalgo M, Ben Younes K, Body S, Ben Aissa-Fennira, Haelewyn B, Sola B. Agonists of estrogen receptor $\beta$ have limited anti-myelome activity. Blood e-Letters, September 15 , 2015. http://www.bloodjournal.org/content/123/13/2054

9. Ladikou EE, Kassi E. The emerging role of estrogen in B cell malignancies. Leuk Lymphoma. 2017; 58:528-539.

10. Moros A, Bustany S, Cahu J, et al. Antitumoral activity of lenalidomide in in vitro and in vivo models of mantle cell lymphoma involves the destabilization of cyclin D1/p2 $7^{\mathrm{KIP} 1}$ complexes. Clin Cancer Res 2014;20:393-403.. 


\title{
Figure 1. ER $\beta$ are present on $M C L$ cells but $E R \beta$ agonists do not affect migration, invasion, nor angiogenesis
}

\begin{abstract}
A. Proteins were purified from cultured MCL cell lines including GFP/mCherry/Luc-expressing cells with the M-PER ${ }^{\mathrm{TM}}$ Mammalian Protein Extraction Reagent (Thermo Fisher Scientific), quantified, separated by SDS-PAGE, blotted onto nitrocellulose mambrane and incubated with antibodies against ERß (sc-8974, Santa Cruz Biotech.) or $\beta$-actin (sc-47778) as a control
\end{abstract} for gel loading and transfer. Our procedure has been described previously [10]. A band at 55 $\mathrm{kDa}$, specific for $E R \beta$,is arrowed; * refers to an unspecific band at $75 \mathrm{kDa}$. B. In vivo experiments were conducted in accordance with the recommendations of EEC (86/609/CEE) and with the approval of the Animal Experimental Ethics Committee of our institution (UBCEEA agreement 251/15). Z138-GFP-Luc, REC1-GFP-Luc, JeKo1-mCherry-Luc, and Granta519-GFP cell lines were engineered using lentivirus or retrovirus infections. Male NSG mice, $n=3$ per group (age 6-8 weeks), were injected i.v. with $10^{7}$ cells in a final volume of $100 \mu \mathrm{l}$. The same day, mice were separated into three groups receiving: vehicle $(0.01 \%$ DMSO), DPN or ERB-041 both at the concentration of $1 \mathrm{mg} / \mathrm{kg}$. Drugs and vehicle were injected i.p. 5 days a week. Tumor engraftment was determined weekly by bioluminescence imaging (BLI). For this aim, mice were injected i.p. with $75 \mathrm{mg} / \mathrm{kg}$ of D-luciferine and then analyzed on an Aequoria Luxiflux bioluminescent device equipped with an ORCA-ER camera (Hamamatsu). Mice were euthanized at day 31 (Z138-Luc) or day 41 (REC1-GFP-Luc). Endpoint BLI signal is shown for each treatment group. C. MCL cells were treated in vitro with DPN or ERB-041 (100 nM or $1 \mu \mathrm{M}$ for $48 \mathrm{~h}$ or $72 \mathrm{~h}$ ) or vehicle and assayed for migration. 
Cells $\left(5 \times 10^{5}\right.$ cells per insert) were suspended in RPMI 1640 medium containing $0.5 \%$ bovine serum albumin (BSA). They were seeded in the top chamber of transwell inserts (Millicell ${ }^{\circledR}$ Hanging Cell Culture Inserts $5 \mu \mathrm{m}$ PET, Millipore). Filters were transferred to wells containing RPMI 1640 medium with recombinant human stromal cell-derived factor 1 (SDF1, $200 \mathrm{ng} / \mathrm{ml}$, R\&D Systems) as chemoattractant. Plates were then incubated for $4 \mathrm{~h}$ at $37^{\circ} \mathrm{C}$, and the number of cells migrated in the lower chambers was counted by flow cytometry. As an example, the results obtained for the $Z 138$ cell line treated with 0.1 or $1 \mu \mathrm{M}$ ERB-041 or DPN for $48 \mathrm{~h}$ are shown. The percentage of migrating cells (treated vs. vehicle) for each culture condition is plotted on the graph. D. HUVECs were plated onto a layer of Matrigel (BD Bioscience) at a density of $4 \times 10^{4}$ cells/well. Cells were treated with supernatants of ERB041-treated (100 nM or $1 \mu \mathrm{M}$ for $4 \mathrm{~h}$ ) or vehicle-treated cells as a control. After $24 \mathrm{~h}$, tubular structures were photographed under a microscope (Olympus IX2-SL). The number of formed capillary tubes was counted in 11 independent fields (Fig S5A) of each well from each culture. The experiment has been done twice with triplicate samples. The number of tubes are plotted in the histograms. E. The concentration of VEGF was measured with an ELISA assay (Quantikine ELISA Human VEGF, R\&D systems) using the supernatants of Granta519 and JeKo-1 cells treated by ERB-041 (1 $\mu \mathrm{M}$ for $48 \mathrm{~h}$ ) according to the manufacturer's recommendations. Samples were assayed in triplicate. The concentration of synthetized VEGF in each culture condition was deduced from the standard curve shown in Fig S5B . ns, non significant; ${ }^{*}, p<0.05 ;^{* *}, p<0.01 ; * * *, p<0.001$ with the Student's $t$-test. 
Table 1. Flow cytometry analysis of infiltrated organs in engrafted NSG mice

\begin{tabular}{|c|c|c|c|c|c|c|c|c|}
\hline Cell line & Mouse & Spleen & Blood & $\begin{array}{l}\text { Bone } \\
\text { marrow }\end{array}$ & Liver & Lung & Kidney & Testis \\
\hline \multirow[t]{3}{*}{ JeKo1-mCherry-Luc* } & J1 & 5 & no & 44 & no & nd & nd & no \\
\hline & $\mathrm{J} 2$ & 15 & no & 59 & no & nd & nd & no \\
\hline & J3 & 7 & 7 & 45 & no & nd & nd & no \\
\hline \multirow[t]{3}{*}{ Z138-Luc** } & Z3 & 22 & no & 68 & no & nd & nd & nd \\
\hline & Z4 & 24 & no & 75 & no & nd & nd & nd \\
\hline & Z5 & 38 & no & 82 & no & nd & nd & nd \\
\hline \multirow[t]{3}{*}{ REC1-GFP-Luc*** } & R4 & no & no & 4 & nd & nd & nd & nd \\
\hline & R5 & no & no & 3 & no & nd & nd & nd \\
\hline & R6 & no & no & 3 & nd & nd & nd & nd \\
\hline \multirow[t]{2}{*}{ Granta519-GFP† } & G1 & 23 & 1 & 57 & 45 & 7 & 9 & no \\
\hline & G4 & 37 & 2 & 21 & 47 & 3 & 10 & $<1$ \\
\hline
\end{tabular}

$*$, in the JeKo1-mCherry-Luc series, three mice were sacrificed at day $23 .{ }^{* *}$, in the Z138-Luc series, three mice were sacrificed at day $30 .{ }^{* * *}$, in the REC1-GFP-Luc series, three mice were sacrificed at day 33. + , in the Granta-GFP series, three mice died unexpectedly at day 17 , two mice were sacrificed at the same day. At the time of euthanasia, indicated organs were collected; single-cell suspensions were prepared, then stained with IOTest ${ }^{\circledR}$ CD20-PE (phycoerythrin, IM1451, FL2) or the corresponding isotype control and analyzed on an Attune acoustic focusing cytometer (Thermo Fisher Scientific). The percentage of positive cells in each organ is indicated in the table. no, no signal; nd, not done. 

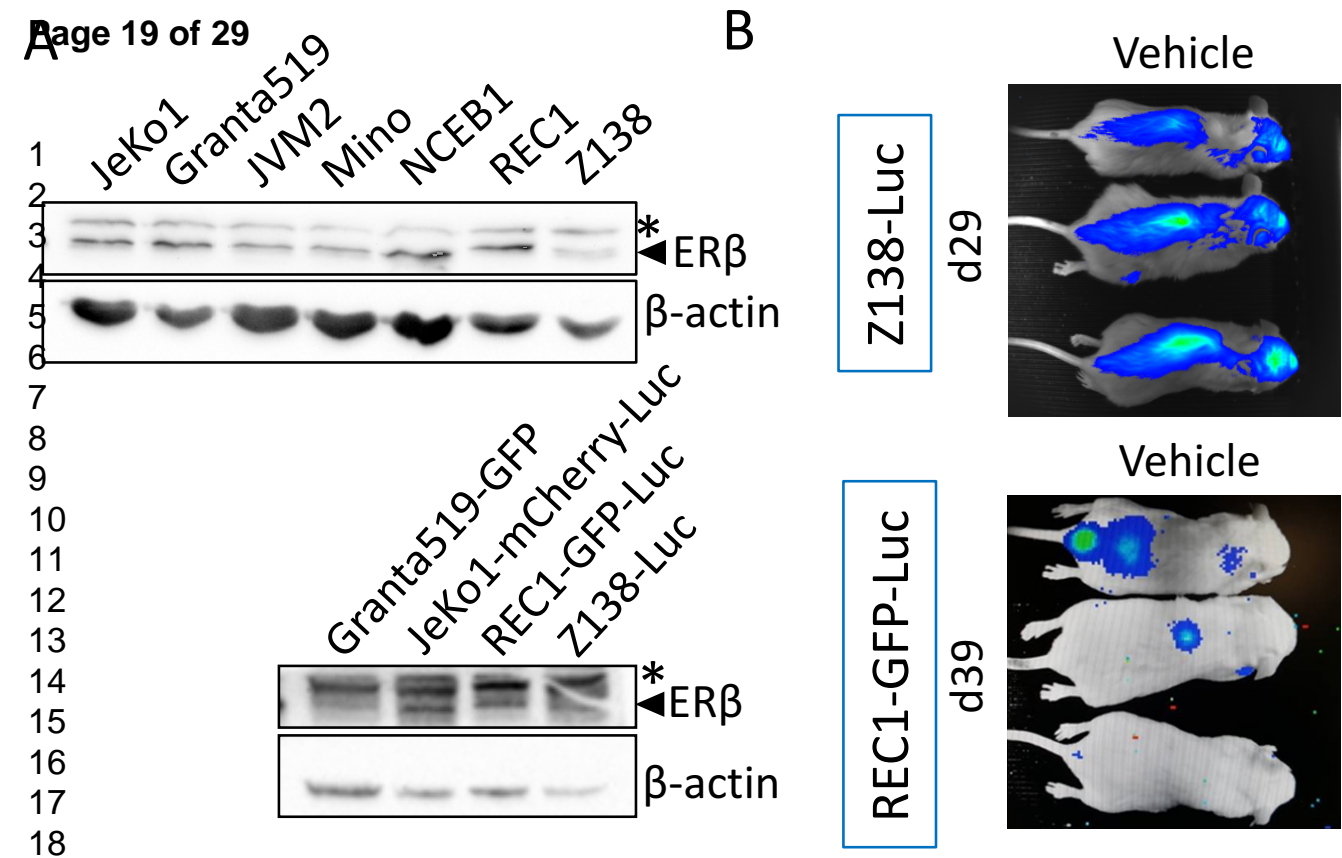

Granta519

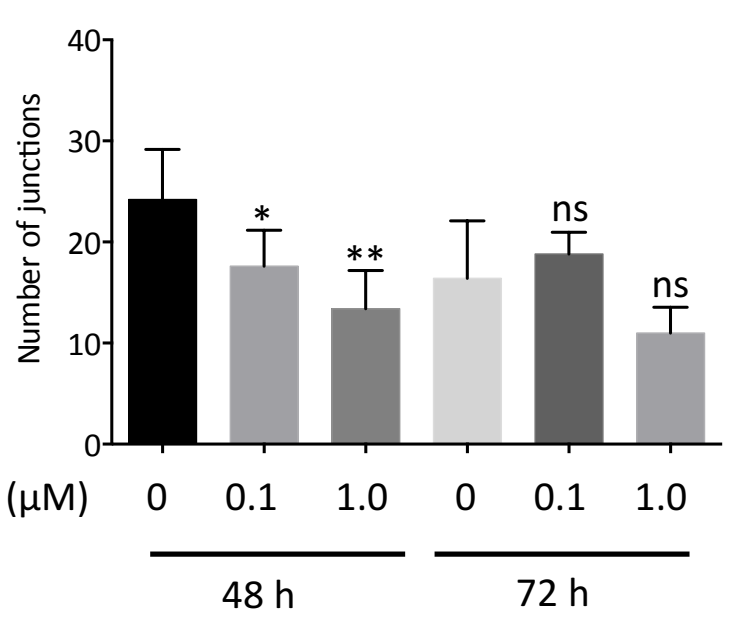

Le Bkprpia and LymphomRB-041
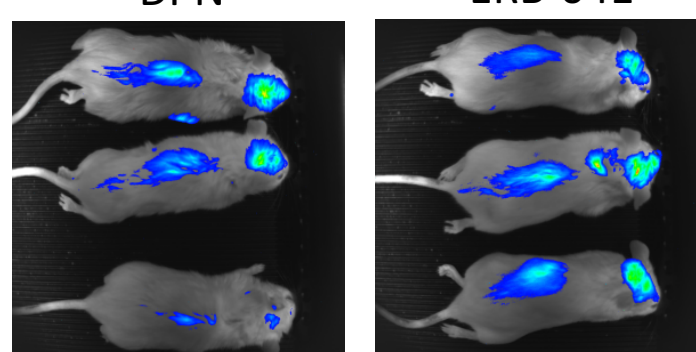

Vehicle
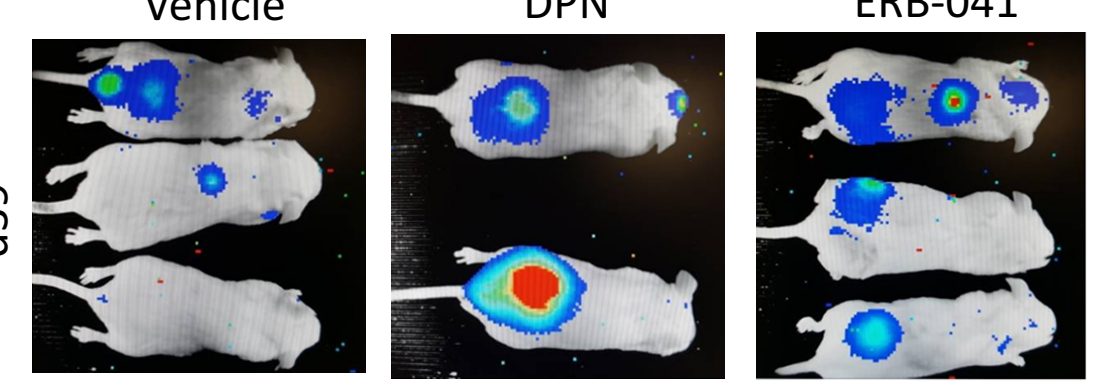

JeKo1

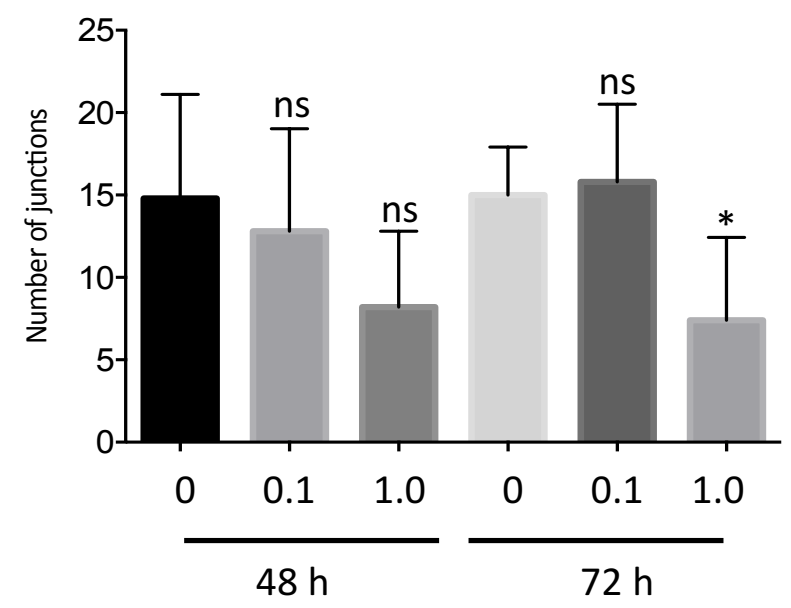

URL: http://mc.manuscriptcentral.com/glal
C

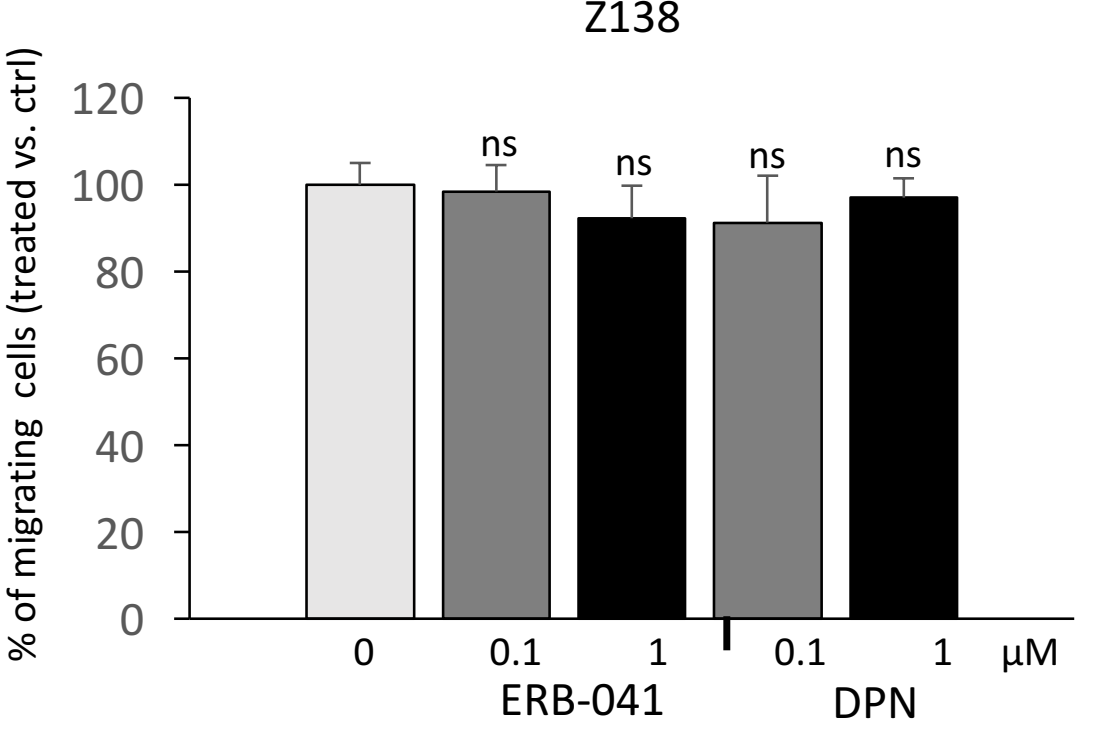

E

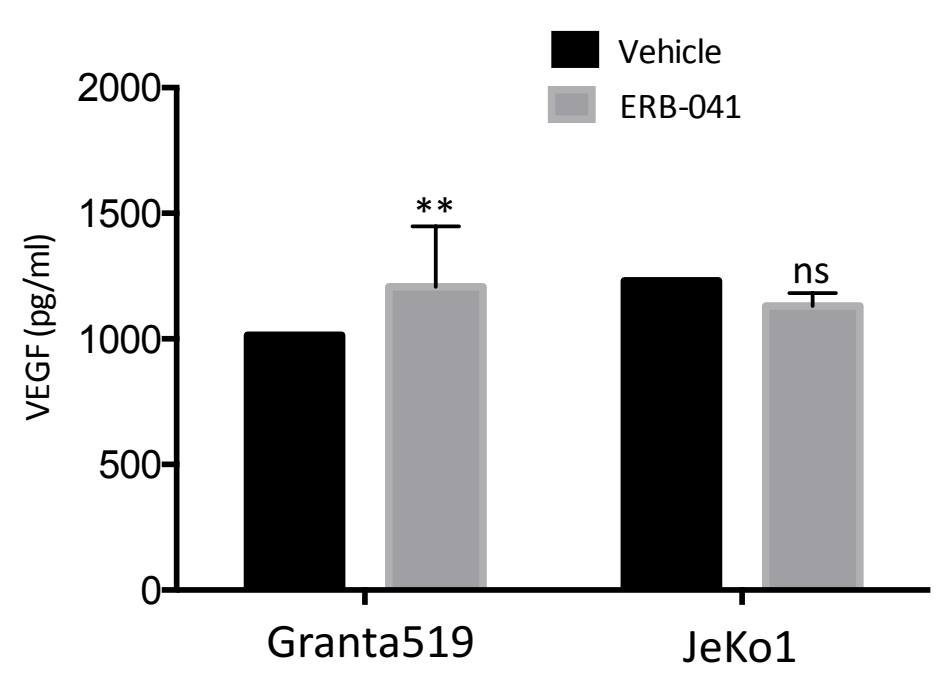




\section{Additional informations}

\section{Additional methods}

\section{Cell culture and cell proliferation measurement}

MCL cell lines have been described previously (Moros et al, 2014). Cell lines were maintained in culture in RPMI 1640 medium (Lonza) supplemented with 10-20\% FCS (PAA Laboratories), $2 \mathrm{mM}$ L-glutamine and antibiotics (Lonza) in a humid atmosphere at $37^{\circ} \mathrm{C}$. Cell authentication was done by short tandem repeat (STR) profiling (IdentiCell, Aarhus, Denmark).

Cell proliferation was assesses by an MTS assay (3-(4,5)-dimethylthiazol-2-yl-)2,5diphenyltetrazolium bromide) assay, here the CellTiter $96^{\circledR} \mathrm{AQ}_{\text {ueous }}$ One Solution 5 promega) according to the supplier's instructions.

\section{Transwell migration and invasion assays}

For migration assay, $5 \times 10^{5}$ cells in serum-free medium plus $0.5 \%$ BSA were added to the top chamber of 24-well inserts (Costar Transwell ${ }^{\circledR}$ Permeable Support, pore size $5 \mu \mathrm{m}$ ). For invasion assay, the same number of cells were seeded in transwell inserts coated with extracellular matrix ECM obtained from Engelbrecht-Holm-Swarm mouse sarcoma (SigmaAldrich). Medium supplemented with SDF1 $(200 \mathrm{ng} / \mathrm{ml}$ ) or not (for control), was added in the bottom chambers. Plates were incubated for $4 \mathrm{~h}$ (migration) or $24 \mathrm{~h}$ (invasion) at $37^{\circ} \mathrm{C}$. Migrating and invaded cells present in the lower chambers were counted by flow cytometry. The accuracy of cell count was checked by the use of fluorescent particles added in the chambers (Accucount Fluorescent particles, SpheroTech).

\section{Tube formation assay}


HUVECs were plated onto a layer of Matrigel (BD Bioscience) at a density of $4 \times 10^{4}$ cells/well in 24-well plates. Immediately after, cells were treated with supernatants of DPN/ERB-041treated (100 nM or $1 \mu \mathrm{M}$ for $48 \mathrm{~h}$ ) or vehicle-treated MCL cells. Cultures were observed $24 \mathrm{~h}$ later under an inverted microscope (Olympus IX2-SL, X 40 magnification) and the number of formed capillary tubes counted on 11 representative fields. A junction was recorded when a tube was bound to, at least, one another tube.

\section{Western blotting}

Proteins were purified from cultured MCL cell lines including GFP/mCherry/Luc-expressing cells with the M-PER ${ }^{\mathrm{TM}}$ Mammalian Protein Extraction Reagent (Thermo Fisher Scientific), quantified, separated by SDS-PAGE, blotted onto nitrocellulose paper and incubated with antibodies against ERß (sc-8974, Santa Cruz Biotech.) or $\beta$-actin (sc-47778) as a control for gel loading and transfer. Our procedure has been described previously (Moros et al, 2014).

\section{$M C L$ cells engraftment in immunocompromised mice}

In vivo experiments were conducted in accordance with the recommendations of EEC (86/609/CEE). They were approved by the Animal Experimental Ethics Committee of our institution (UB-CEEA agreement 251/15 in Spain). Z138-GFP-Luc, REC1-GFP-Luc, JeKo1mCherry-Luc, Granta519-GFP cell lines were engineered using lentiviruses or retroviruses. Male NSG ( $n=6$ per group) mice (age 6-8 weeks) were injected i.v. with $10^{7}$ cells in a final volume of $100 \mu \mathrm{l}$. Tumor engraftment was determined weekly by bioluminescence imaging (BLI). Mice were injected i.p. with $75 \mathrm{mg} / \mathrm{kg}$ of D-luciferine and then analyzed with a Aequoria Luxiflux bioluminescent device quipped with an ORCA-ER camera (Hamamatsu). Photon emissions were captured through the whole mouse body. At the end of the 
experiment mice were euthanized. Then, infiltrated organs were collected; single-cell suspensions were prepared, then stained with IOTest ${ }^{\circledR}$ CD45-PE (phycoerythrin, IM1451, FL2) or the corresponding isotype controls as recommended by the supplier.

For ER $\beta$ agonists treatment, mice were either engrafted with Z138-Luc or REC1-GFP-Luc. The same day, mice were separated into three groups ( $n=3$ in each one), one receiving DPN (1 $\mathrm{mg} / \mathrm{kg})$, another ERB-041 $(1 \mathrm{mg} / \mathrm{kg})$, and the last one vehicle (0.1\% DMSO). Mice were treated five days a week. Mice of the $\mathrm{Z138}$ group were euthanized at day 29 , of the REC1 group, at day 39. BLI was recorded as mentioned before.

\section{Additional figure legends}

\section{Supplemental Fig S1}

Six-week old NOD-scid IL2ry ${ }^{\text {null }}$ (NSG) male mice were injected in the caudal vein with $10^{7}$ JeKo1-mCherry-Luc, Z138Luc, or REC1-GFP-Luc cells. Mice were weekly analyzed for BLI starting one week after cells injection.

\section{Supplemental Fig S2. Effect of DPN and ERB-041 treatment on MCL tumor cell infiltration} in vivo.

NSG mice were injected intravenously with Z138-Luc cells and received a daily dose of DPN (D, $1 \mathrm{mg} / \mathrm{kg}$ ), ERB-041 (E, $1 \mathrm{mg} / \mathrm{kg}$ ) or the equivalent volume of vehicle (V), for up to 14 days. Mice were then sacrificed and human CD45+ malignant $B$ cells were recounted on a cytometer from spleen, brain, bone marrow extracts and in peripheral blood samples, as described in the methods section. Shown are the relative mean fluorescence intensity (MFIR) values between CD45-derived fluorescence and isotypic control, calculated in the different compartments and for each treatment group (statistical significance: ${ }^{*} p<0.05$ ).

\section{Supplemental Fig S3}


Granta519-GFP, JeKo1-mCherry-Luc, REC1-GFP-Luc and Z138-Luc cells were either treated with the vehicle (0.1\% DMSO) or various concentrations $\left(0.1-10^{4} \mathrm{nM}\right)$ DPN or ERB-041 for 48 h. Cell proliferation was assessed using an MTS assay (CellTiter $96^{\circledR}$ AQueous One Solution Cell Proliferation Assay, Promega). The experiment was performed twice with triplicate samples with similar results. The means \pm SD from one representative experiment are reported on the histograms. ${ }^{*}, p<0.05 ;{ }^{* *}, p<0.01 ; * * *, p<0.001 ;$ ns, not significant with the Student's $t$-test.

\section{Supplemental Fig S4}

A. Left panel. JeKo1 and Z138 cultured cells were were seeded into the top chamber of transwell inserts. Inserts were transferred into wells containing medium with SDF1 or without SDF1 (Ctrl) and cells were allowed to migrate for $4 \mathrm{~h}$. Cells present in the bottom well were then counted. Three independent inserts were seeded per experiment; the experiment was performed three times. Mean numbers of migrating cells \pm SD were plotted on the graph. Middle and right panels. Granta519 and JeKo1 cells were treated in vitro with vehicle or ERB-041 (0.1 or $1 \mu \mathrm{M})$ for $48 \mathrm{~h}$ or $72 \mathrm{~h}$. Then they were seeded and assayed for migration as described before. Three independent inserts were seeded per experiment; the experiment was performed three times. The percentage of migrating cells \pm SD was plotted on the graph. B. Left panel. JeKo1 cells were seeded in transwell inserts coated with extracellular matrix (ECM) proteins. Inserts were transferred into wells containing medium with SDF1 or without SDF1 (Ctrl). Cells were allowed to invade ECM for $24 \mathrm{~h}$. The number of invaded cells is plotted on the graph. The experiment has been carried out twice with triplicate samples. Middle and right panels. JeKo1 and Z138 cells were treated with vehicle, DPN (0.1-1 $\mu \mathrm{M})$ or ERB-041 (0.1-1 $\mu \mathrm{M})$ for $48 \mathrm{~h}$ and seeded in ECM-coated transwell inserts. Inserts were incubated for $24 \mathrm{~h}$ and the number of cells present in the bottom wells 
counted. The experiment was repeated three times with triplicate samples. The mean ratios (treated vs. ctrl) \pm SD are plotted on the graph. ns, not significant; ${ }^{*}, p<0.05 ; * *, p<0.01$ $* * *, p<0.001$ in $t$-tests.

\section{Supplemental Fig S5}

A. HUVECs were plated onto a layer of Matrigel (BD Bioscience) at a density of $4 \times 10^{4}$ cells/well in the presence of supernatants from JeKo1 and Granta519 cells previously treated with ERB-041 (0.1 or $1 \mu \mathrm{M}, 4 \mathrm{~h}$ ) or with vehicle as a control. After a $24 \mathrm{~h}$-incubation period, cells were photographed under a microscope (Olympus IX2-SL). The number of branch points (circled in red) with at least two branches, corresponding to newly formed capillary tubes was counted on representative fields. The experiment has been done twice with triplicate samples.

B. The quantification of produced VEGF was done using the Quantikine ELISA kit (R\&D systems) according to the manufacturer' instructions on a Victor X4 plate-reader (Perkin Elmer). The standard curve was drawn from the $O D$ at $450 \mathrm{~nm}$ of calibrated VEGF concentrations raging from $10^{3}$ to $15.6 \mathrm{pg} / \mathrm{ml}$.

\section{Additional reference}

Moros, A., Bustany, S., Cahu, J., Saborit-Villarroya, I., Martinez, A., Colomer, D., Sola, B. \& Roué, G. (2014) Antitumoral activity of lenalidomide in in vitro and in vivo models of mantle cell lymphoma involves the destabilization of cyclin D1/p27KIP1 complexes. Clinical Cancer Research, 20, 393-403. 


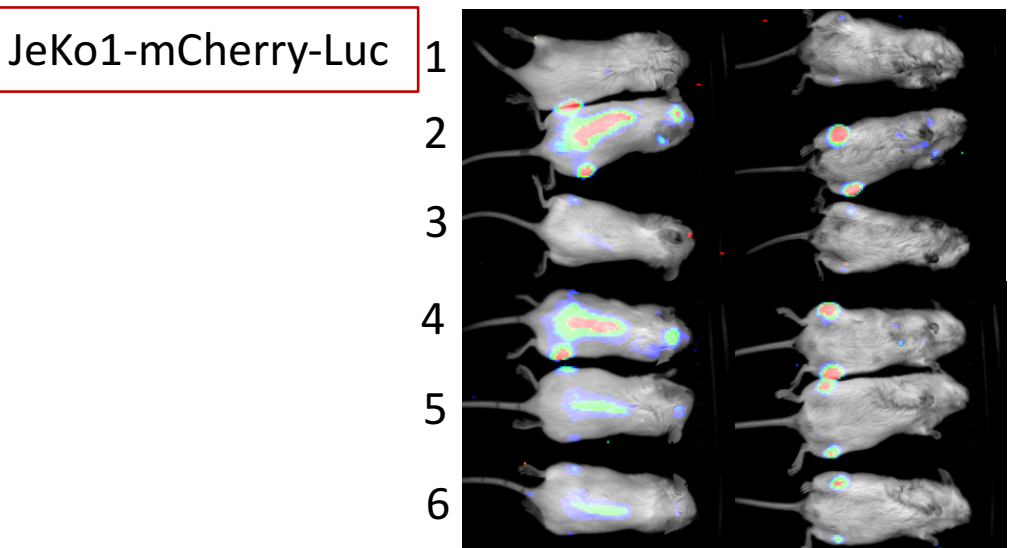

Z138-LuC 1

3

4 no signal

5

6

REC1-GFP-LuC 1 2

3

4

5

6 d8

d15
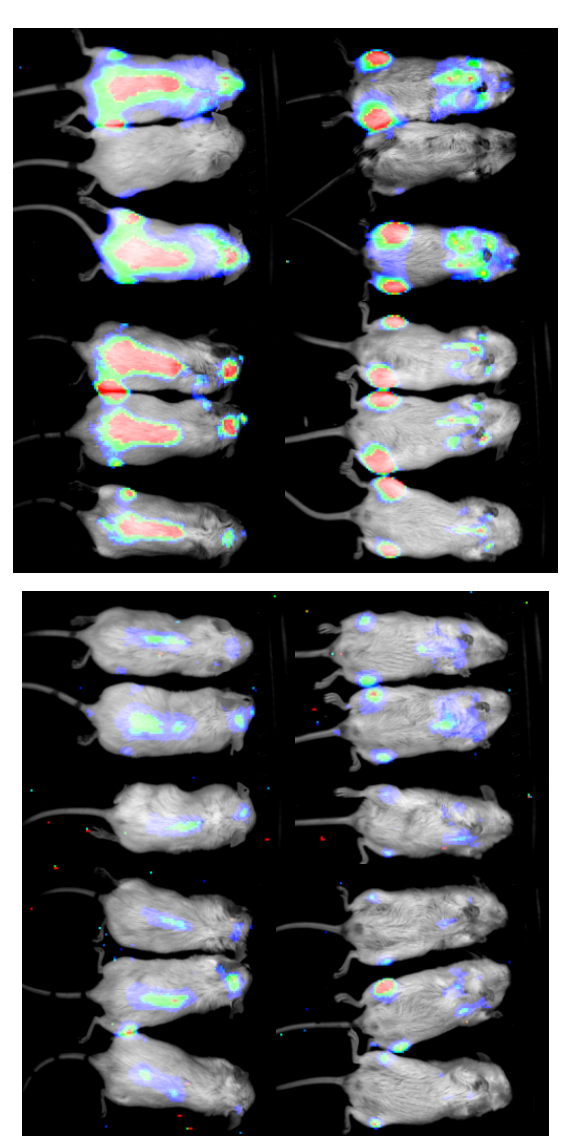

no signal

no signal
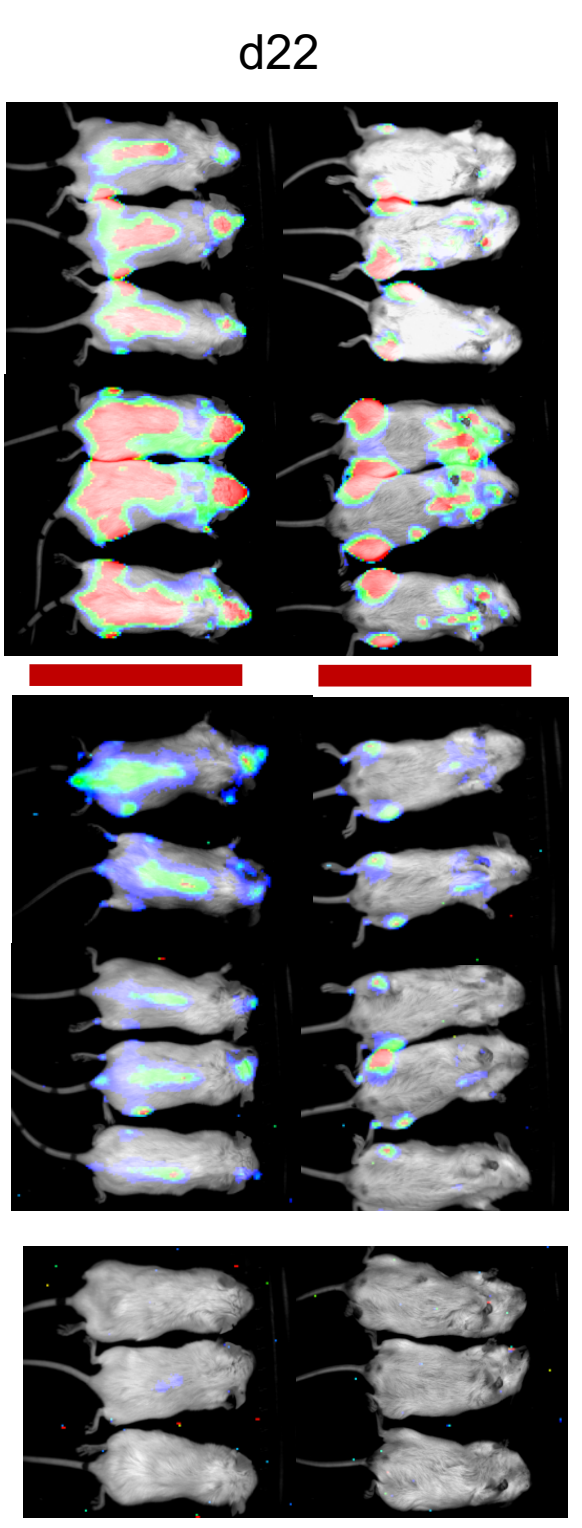

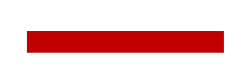

d29

d32
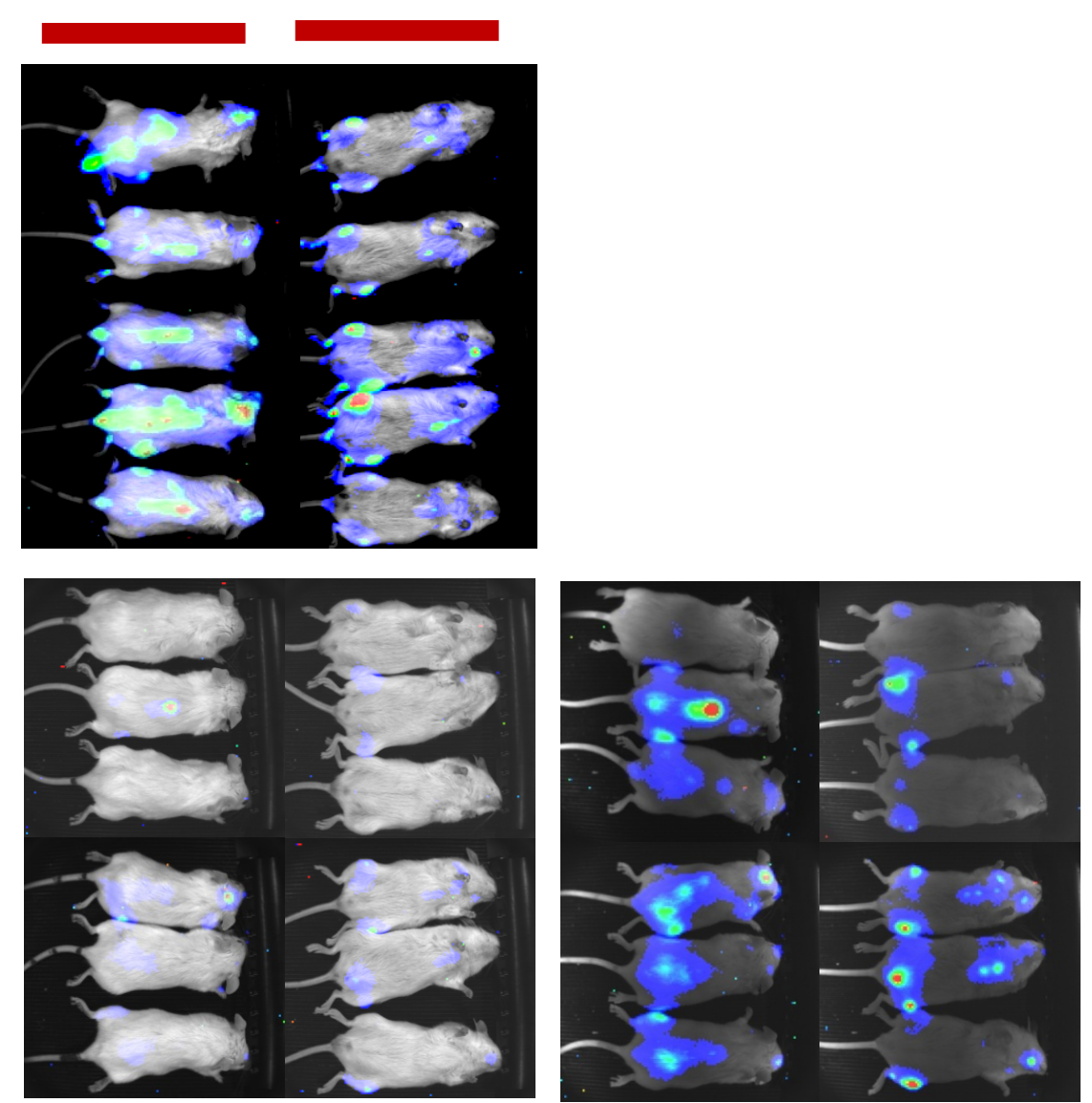

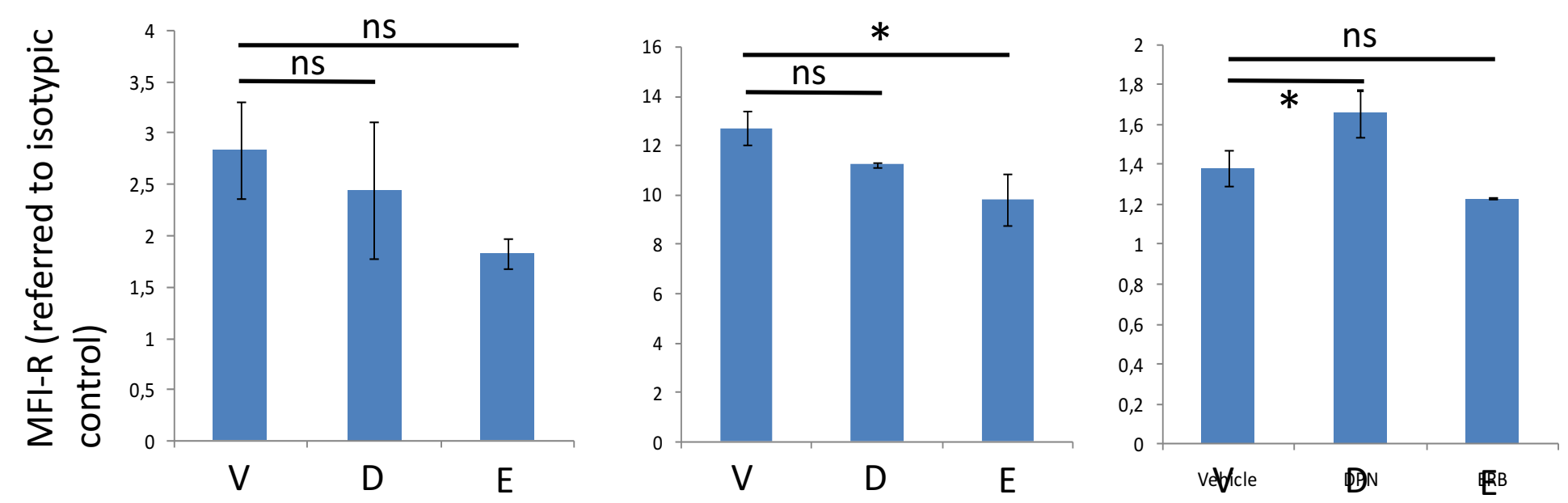

Fig S2 

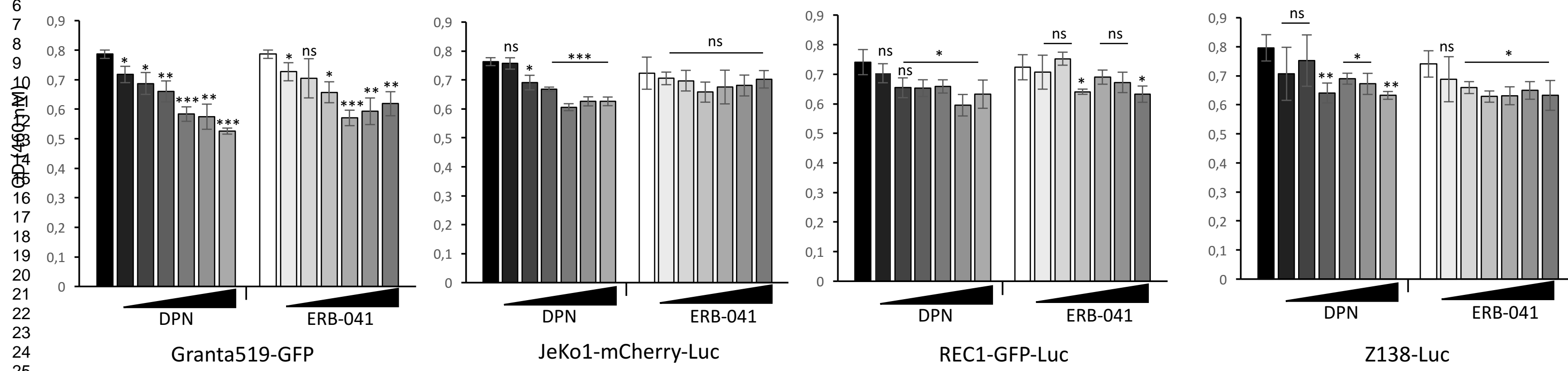

Fig S3 
A

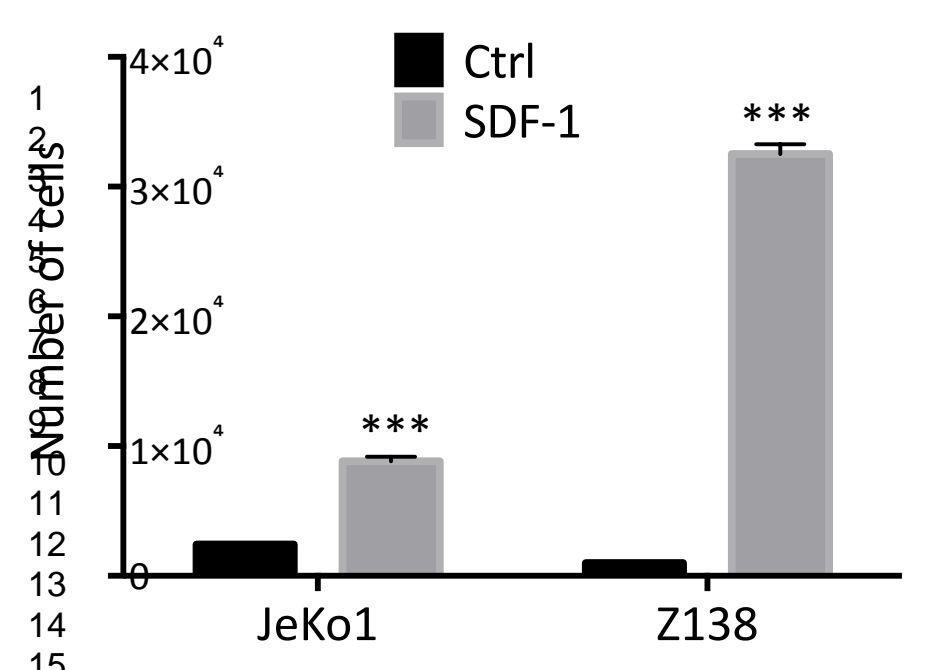

Leukemia and Lymphoma
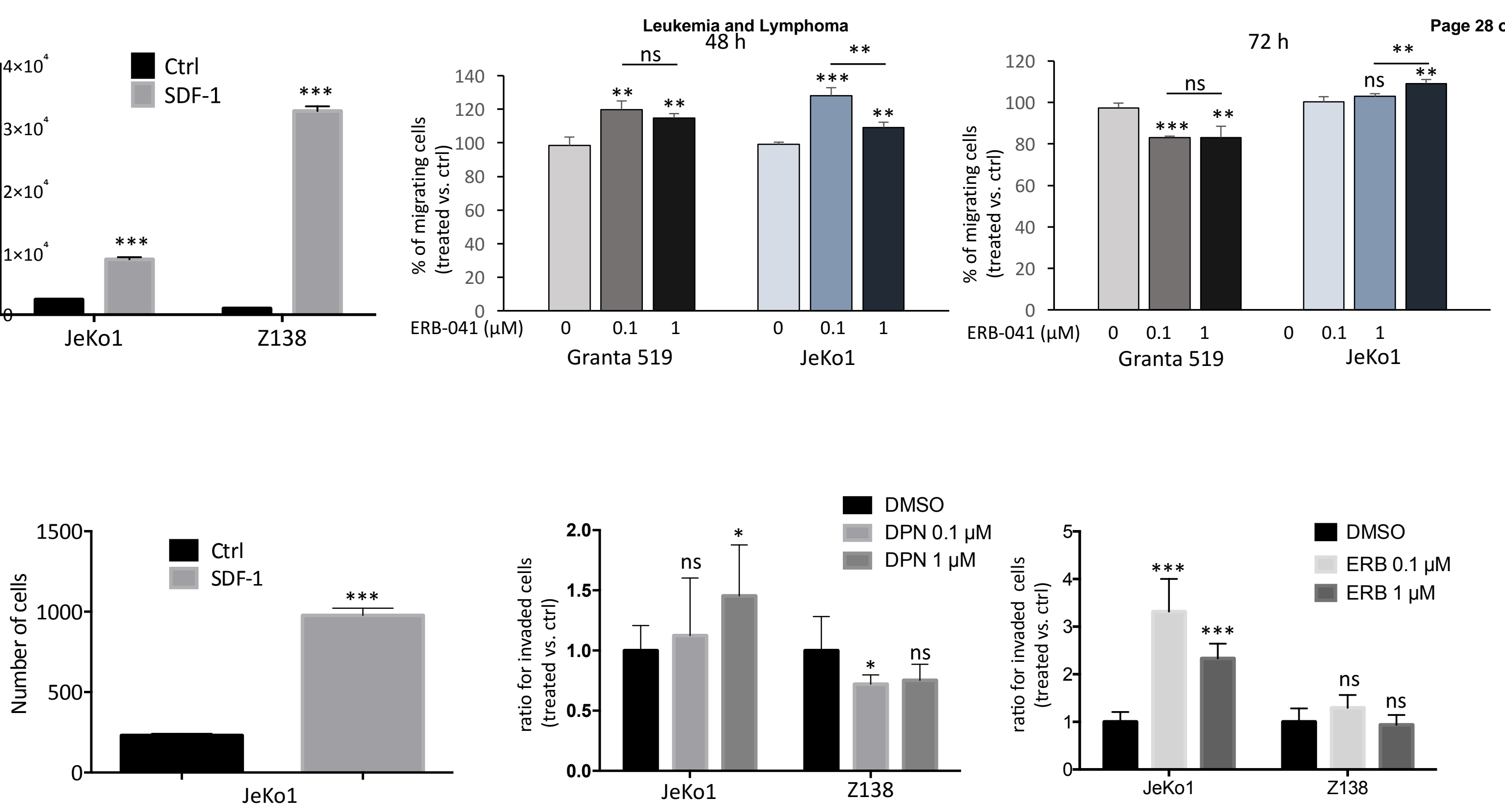

URL: http://mc.manuscriptcentral.com/glal

Fig S4 
